\title{
Effect of Amaranthus Viridis Extract on Growth as Well As Induction of Defense in Chickpea
}

\author{
Sheeba Menon ${ }^{1}$ \\ ${ }^{1}$ Biology Department, \\ K K Shah Jarodwala Maninagar Science College, \\ Maninagar, Ahmedabad - 380008, \\ Gujarat, India,
}

\author{
Janki Thakker ${ }^{2}$ \\ ${ }^{2}$ Department of Biotechnology, \\ P D Patel institute of Applied Science, \\ Charotar University of Science and Technology, \\ Changa, Anand-388421, Gujarat, India,
}

\begin{abstract}
Amaranthus viridis $\mathrm{L}$ is sometimes eaten as cooked vegetable, fodder for cattle and green manure; the leaves are diuretic and purgative and are used for treating inflammations, boils and abscesses, gonorrhoea, orchitis and haemorrhoids. Cicer arientinum $\mathrm{L}$ (Chick pea) seeds were treated with extract, leachate and dried leaves of the plants. After 2 hours, coated Chick pea seeds were transferred to individual pots and kept for germination. The vegetative parameters were calculated after fifteen days. The study of these vegetative parameters indicated that there is positive plant to plant interaction. Treated Chick pea plants showed significant increase in rootshoot length, number of leaflets, fresh and dry weight as compared to plant grown with distilled water. Change in defense enzymes like Peroxidase, Phenylalanine ammonia lyase and phenolics were noted in extract treated plants. Extract can be used for growth promotion as well as defense induction.
\end{abstract}

Key Words - Amaranthus viridis, vegetative parameters, Peroxidases, Phenyl ammonia lyase, Poly phenol oxidase

\section{INTRODUCTION}

A family of about 65 genera and 900 species, Amaranthaceae are mostly distributed in tropical but also in temperate regions. About 18 genera and over 50 species have been reported from India (1). Amaranthus viridis.L grows annually as an erect, monoecious herb up to 100$300 \mathrm{~cm}$ tall, much branched. Leaves are alternate, simple, petiolate, base tapering, margins entire, apex acute or obtuse or retuse or emarginated, Blade glabrous (2). Amaranthus viridis is also been used as a medicinal herb (3).

Chick pea is an important source of cheap protein with high energy and nutritive value (4). Chick pea is the $3^{\text {rd }}$ most important pulse crop (5). Chick pea seeds contain Malic and Oxalic acids which lower blood cholesterol levels (6).

Chemicals with Allelopathic potential are present in a variety of plant tissues (7). Allelopathy effects specific plant processes such as cell division and elongation, action of inherent growth regulators, mineral uptake, photosynthesis, respiration, stomatal opening, protein synthesis and membrane permeability (8).

The aim of the present study was to analyse the effect of the extract of Amaranthus viridis $\mathrm{L}$ leaves on germination and growth as well as on the defense enzymes of Chick pea. The Bioassays was carried out to study the effect on Chick pea leaves and compared with control.

\section{MATERIALS AND METHODS}

\section{Preparation of Plant extracts}

Disease free and fresh Amaranthus viridis L. plant was collected from Changa campus. The leaves were separated and washed under tap water. The fresh leaves were used to prepare $4 \%$ fresh leaf extract and leachate. $4 \%$ fresh leaf extract was prepared by crushing $4 \mathrm{~g}$ fresh leaves in distilled water. For Leachate preparation $250 \mathrm{~g}$ of Fresh Amaranthus leaves were soaked for $24 \mathrm{~h}$ in $500 \mathrm{ml}$ distilled water. Similarly, $10 \mathrm{~g}$ of leaves were oven dried at $55-60^{\circ} \mathrm{C}$ for 24 $\mathrm{h}$ and used to make dried leaf paste with required quantity of water.

\section{POT CULTURE}

Chick pea seed were purchased from D Mart store, Ahmedabad. Ten non-sterilized Chick pea seeds each were soaked in 4\% Amaranthus fresh leaf extract, Amaranthus fresh leaf leachate and coated with Amaranthus dried leaf paste for $2 \mathrm{~h}(\mathbf{9})$. After $2 \mathrm{~h}$ the treated Chick pea seeds were shifted to pots and kept for germination under natural conditions. A total of three replications of treated Chick pea seeds were kept undisturbed and watered at regular intervals. Chick pea seeds with distilled water were kept as control. The readings for vegetative parameters of Chick pea plant like germination percentage, root length, shoot length, number of lateral roots and leaflets, fresh and dry weight was taken after 15 days regularly.

\section{ENZYMATIC (DEFENSIVE) ASSAYS}

The Enzymatic (Defensive) Peroxidase activity in Chick pea leaves were determined by using method developed by (10) and absorbance was measured at $420 \mathrm{~nm}$ by UV visible Spectrophotometer (Shimadzu). Phenylalanine ammonia lyase were determined by using method developed by (11) and absorbance was measured at $270 \mathrm{~nm}$ by UV visible Spectrophotometer (Shimadzu). Poly phenol oxidase were determined by using method developed by (12) and absorbance was measured at $280 \mathrm{~nm}$ by UV visible Spectrophotometer (Shimadzu).

\section{RESULTS}

The germination per cent increase in Chick pea seeds after treatment was $90 \%$ with Amaranthus dried leaf paste, $80 \%$ with fresh leaf extract and $70 \%$ with fresh leaf leachate. Meanwhile the germination per cent was $30 \%$ with distilled 
water (control) (Table-1). There was a gradual increase of treated Chick pea plant in all the vegetative parameters after 15 days as compared to control (Table-2). Increase in POX,
PAL and PPO was found in treated Chick pea leaves with 4\% fresh leaf Amaranthus extract, fresh leaf leachate and dried leaf paste as compared to control (Table-3,4)

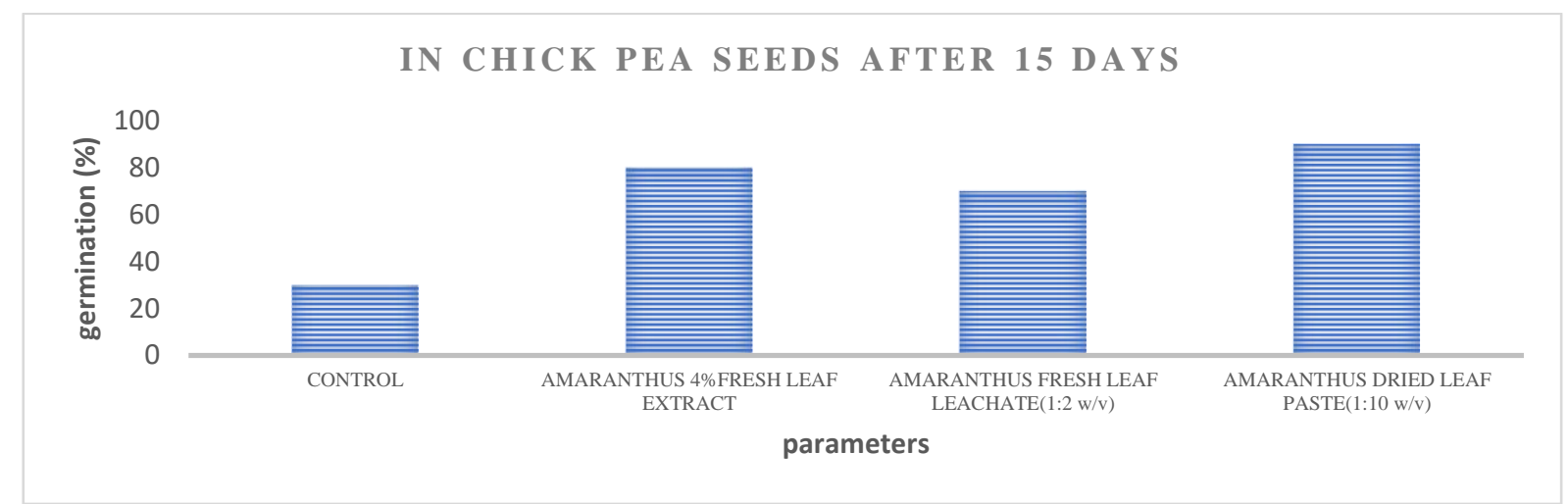

Graph-1 Germination (\%) in Chick pea seeds after 15 days

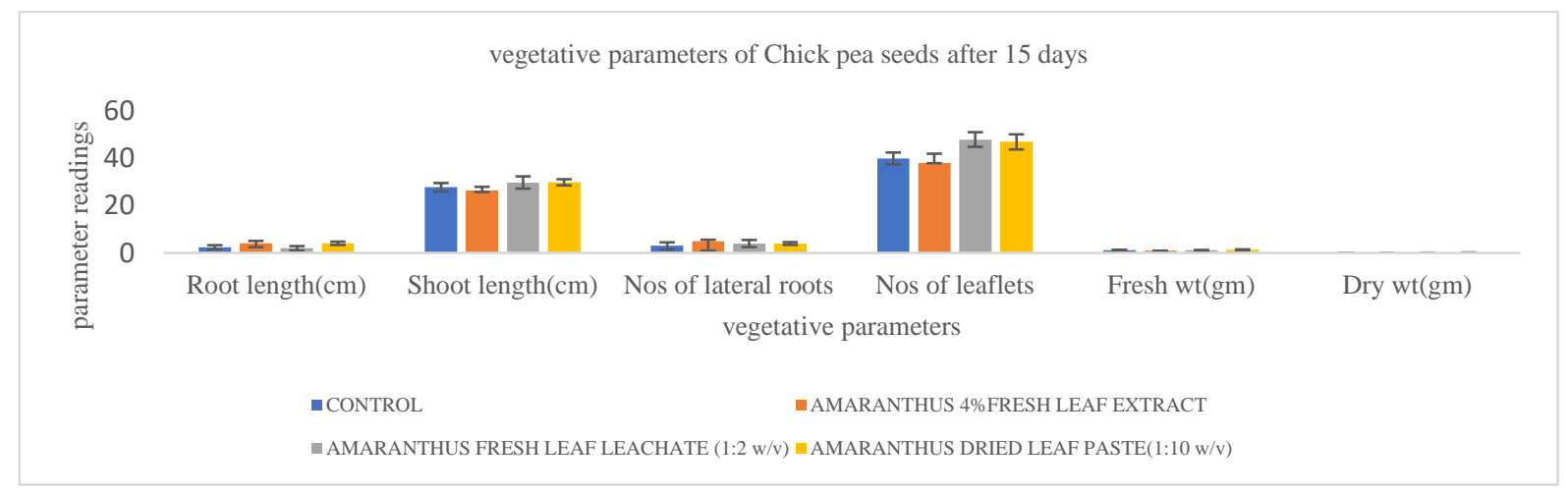

Graph - 2 Vegetative parameters of Chick pea seeds after 15 days

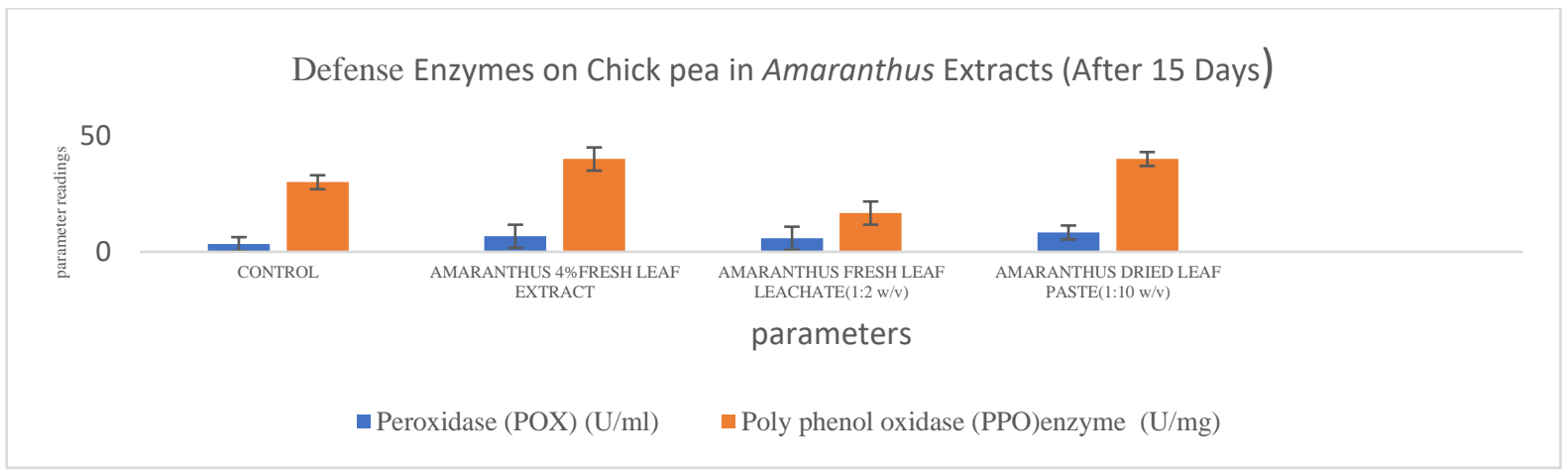

Graph- 3 Defense enzymes (POX and PPO) on Chick pea in Amaranthus extracts (after 15 days)

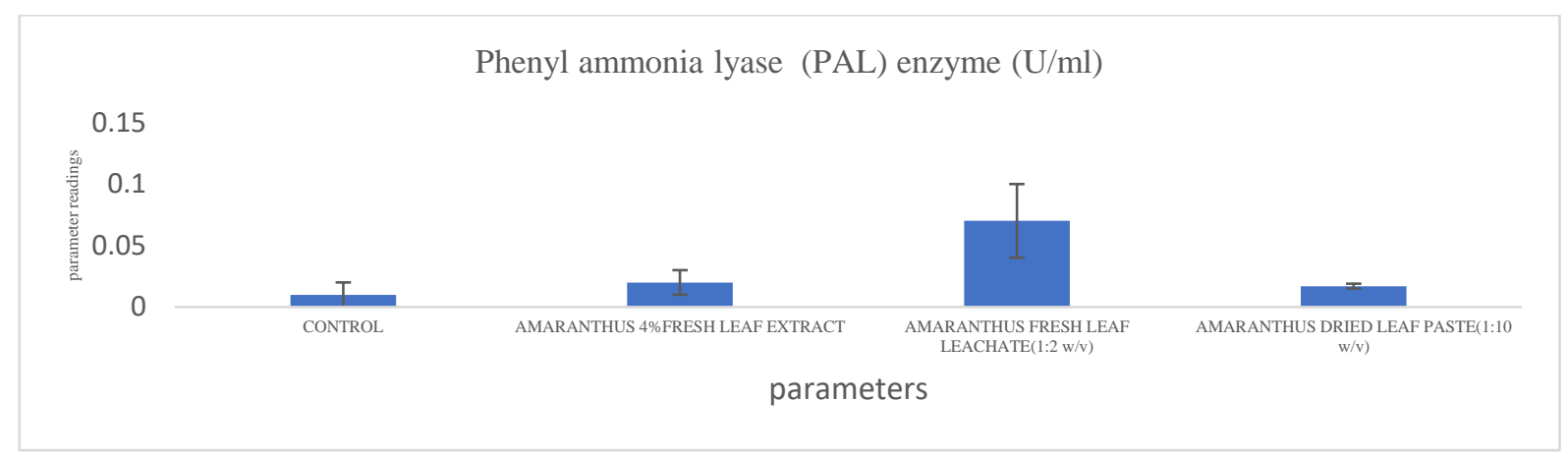

Graph- 4 Defense enzymes (PAL) on Chick pea in Amaranthus extracts (after 15 days) 


\section{DISCUSSION}

According to study conducted by Jabeen et al., (13) the low amount (10gm) of weed powder increased the amount of organic matter in soil, resulting in the better growth than the control. Under the present study the vegetative parameters of treated Cicer seeds showed better growth than the control. Allelochemicals can stimulate or inhibit plant growth depending on their concentration (14). The presence of defence enzymes like peroxidase, poly phenol oxidase and phenylalanine ammonia lyase was analysed and was more in treated Cicer leaves. The defence enzymes extend mechanical support to the plant. Peroxidases play important role in lignifying cell walls and thus increasing plant resistance (10). Phenyl ammonia lyase is involved in phenolics synthesis including phytoalexins and suberin (11). Poly phenol oxidase helps in the production of brown pigments (12).

\section{CONCLUSION}

Based on the analysis carried out Amaranthus viridis fresh and dried leaves have the potential to promote germination. It shows that Amaranthus fresh and dried leaves have both the potential, one is germination and exceptional defence parameters.

\section{ACKNOWLEDGEMENT}

First of all, the authors are thankful to the Principal and staff members of K K Shah Jarodwala Maninagar Science college, Ahmedabad for allowing to finish my research work. The authors are also thankful to University Grants Commission (UGC) for awarding 'Teacher fellowship'. The authors are obliged and thankful to Charotar University of Science and Technology for providing necessary facilities

\section{REFERENCES}

[1] Rahman A H M M and Gulshana M I A, 2014. Taxonomy and medicinal uses on Amaranthaceae family of Rajshahi, Bangladesh. Applied Ecology and Environmental Science, 2(2): 54-59
[2] Shah G L, Flora of Gujarat, 1978, Published by S P University, Anand

[3] Malik K; Nawaz F and Nisar N, 2016. Antibacterial activity of Amaranthus viridis. Bulletin of Environment, Pharma and Life Science, 5(4): 76-80

[4] Cokkizgin A, 2012. Botanical characteristics of chick pea genotype (Cicer arientinum $\mathrm{L}$.) under different plant densities in organic farming. Scientific research and essays, 7(4): 498-503

[5] Roy I; Biswas P K; Ali M H; Haque M N and Parvin K, 2016. Growth and reproductive behaviour of chick pea (Cicer arientinum L.) as influenced by supplemental application of Nitrogen, irrigation and hormone. Plant Science today,3(1): 30-40

[6] Snafi A E A, 2016. The medical importance of Cicer arientinumA review. International Organization of Scientific Research Journal of pharmacy, 6(3): 29-40

[7] Dhole J.A; Lone K.D, Dhole G.A and Bodke S.S, 2013 Allelopathic effect of aqueous and ethanolic extracts of some common weeds on seed health of Triticum aestivum.L (Wheat). International $\mathrm{J}$ of current Microbiology and applied sci, 2(6):254260

[8] Deka S.J and Rao.S, 2015. Allelopathic effects on herbaceous weed plant seeds germination. International Journal of Phytopharmacology, 6(4): 225-228

[9] Lalitha P; Shivani K and Rama Rao R, 2012. Parthenium hysterophorus-An economical tool to increase the agriculture productivity. International Journal of Life Science Biotechnology and Pharma research, 1(1): 113-127

[10] Jagdale G.B; Kamoun S and Grewal P. S, 2009. Entomopathogenic nematodes induce components of systemic resistance in plants: Biochemical and molecular evidence. Biological control, 1-8

[11] Sija S L; Potty V P and Santoshlal P S, 2016. Detection of Phenyl ammonia - lyase activity in different plant parts of Anacardium occidentale L. International journal of pharma and Bio Sciences. 7(4), 100-104

[12] Palmer J K, 2017.Banana polyphenol oxidase: Preparation and properties. American society of plant Biologists.508-513

[13] Jabeen N; Ahme M; Shaukat S. S and Iram-Us- Slaam, 2013. Allelopathic effects of Weeds on Wheat (Triticum aestivum L.) germination and growth. Pakistan Journal of Botany, 45(3): 807811

[14] Babar H B; Tanveer A; Muhammad T; Ahsan A; Ahmad A U H; Muhammad, A N and Muhammad M J, 2009. Allelopathic potential of wild onion (Asphodelus tenuifolius) on the germination and seedling growth of chick pea (Cicer arientinum). Weed Biology and Management,9: 146-151 